\title{
Ewe Ovarian Tissue Vitrification: A Model for the Study of Fertility Preservation in Women
}

Franciele Osmarini Lunardi ${ }^{1}$, Casie Shantel Bass ${ }^{2}$, Marcelo Picinin Bernuci ${ }^{3}$, Roberta Nogueira Chaves ${ }^{4}$, Laritza Ferreira Lima ${ }^{1}$, Renato Félix da Silva ${ }^{1}$, José Ricardo de Figueiredo슬 Ana Paula Ribeiro Rodrigues ${ }^{1}$

\author{
${ }^{1}$ School of Veterinary Medicine, Laboratory of Manipulation of Oocytes and Ovarian Preantral Follicles (LAMO- \\ FOPA), State University of Ceara, Fortaleza, Ceara, Brazil \\ ${ }^{2}$ North Dakota State University, Department of Animal Sciences, Fargo, North Dakota, USA \\ ${ }^{3}$ School of Medicine of Ribeirão Preto, Department of Gynecology and Obstetrics, University of São Paulo, São \\ Paulo, Brazil \\ ${ }^{4}$ Health Center, University of Fortaleza (UNIFOR), Edson Queiroz, Fortaleza, Ceará, Brazil
}

Funding: This study received financial support from CAPES.

\begin{abstract}
Emergency in vitro fertilization followed by embryo vitrification is one feasible fertility preservation option for cancer patients. However, its clinical application has several limitations. Hormonal stimulation delays the initiation of oncotherapy and it is contraindicated in hormone-sensitive cancers or for use in pre-pubertal females. Vitrification of ovarian cortical tissue prior to the start of cancer treatment could be utilized for autotransplantation or for in vitro maturation of follicles enclosed in ovarian tissue. Nevertheless, the main concern associated with autotransplantation is the risk of malignant cell re-introduction to the patient, which is non-existent with the use of follicular in vitro culture. Since obtaining ovarian tissues from women for research is challenging and experimental studies are difficult to complete due to ethical issues, exploring the alternative usage of animal models for fertility preservation may provide beneficial insight into the prospects of follicular culture as an alternative for fertility restoration following ovarian tissue vitrification. Similarities between ewe and human ovary structures, as well as in ovarian follicular development dynamics, make the ewe a possible animal model for the study of female fertility preservation. As vitrification of ovarian tissue has the potential to cryopreserve preantral ovarian follicles, the present review will describe the progress of ovarian tissue vitrification studies completed in ewes.
\end{abstract}

Keywords: Vitrification, ewes, preantral follicle, ovary, in vitro culture

\section{INTRODUCTION}

In general, the treatment indicated for women diagnosed with a malignant disease is often aggressive, and may include surgeries, such as oophorectomy. Additionally, other women undergo chemotherapy or radiotherapy; however, all unfortunately result in premature menopause and, consequently, infertility (Amorim et al., 2011a). Advances in assisted reproductive techniques (ART) have greatly increased the possibility of fertility preservation in women submitted to gonadotoxic treatments. The main alternatives routinely used for female fertility preservation are protection of the ovaries against radiation (oophoropexy), emergency in vitro fertilization (IVF) and oocyte vitrification. Although oophoropexy may provide some protection to germ cells, it may also considerably reduce the chances of successful future pregnancies (Wallace et al., 2005).

There are also limitations regarding the use of IVF in cancer patients, as the hormone stimulation protocols needed to obtain mature oocytes delay the beginning of cancer treatment. These hormonal treatments are also not recommended to young pre-pubertal patients or to adult women without a partner (Wallace et al., 2005). However, the damage caused to ovarian germ line cells by radioand/or chemotherapy and the time needed for hormonal therapies would not be inconveniences with the removal and vitrification of ovarian tissue biopsies prior to therapy commencement.

In view of the low availability of ovarian tissue from women and of the ethical and legal aspects involved in these procedures, some animal models, such as sheep, for example, have been extensively utilized in cryopreservation studies (Gosden et al., 1994; Bordes et al., 2005), as well as in in vitro preantral follicular culture (Campbell et al., 2000).

Considering the importance of protecting female fertility, especially in women submitted to gonadotoxic treatments, and the prior usage of sheep as an animal model for humans, this review will: 1) establish a parallel between women and ewes regarding folliculogenesis, and 2) discuss the progress of ovarian tissue vitrification in both species.

\section{Comparison of the main ovarian features be- tween women and ewes}

Women's ovaries are almond-shaped, measuring $3 \mathrm{~cm}$ in length, approximately $1.5-2 \mathrm{~cm}$ in width and are $1 \mathrm{~cm}$ thick. Similarly, in the ewe, the ovaries are also the approximate size of an almond (measuring approximately $1.7 \mathrm{~cm}$ in length, $1.2 \mathrm{~cm}$ in width and $1 \mathrm{~cm}$ thick) (Mohammadpour, 2007).

The formation and differentiation of female gametes, or oogenesis, commences in utero, with primordial germ cells (PGC) migrating from the vitelline sac to the primitive gonads (gonadal ridge). In women, PGC form in the vitelline sac sometime after the first month of pregnancy; in the ewe, the colonization of PGC occurs between days 18 and 28 of embryonic development (Lun et al., 1998). These cells undergo multiple mitotic divisions, populating the developing ovarian cortex. In women, these mitotic divisions occur until near the end of the fifth fetal month (Gartner \& Hiatt, 2003); in ewes, the process ends at approximately 75 days of embryonic development (Smith et al., 1993). At that time, each ovary contains five to seven million oogonia. About one million oogonia are enveloped by follicular cells and survive until the time of birth. The remaining oogonia do not form ovarian follicles (Gartner \& Hiatt, 2003) but instead, they undergo atresia.

The duration of ovarian folliculogenesis (period of 
follicular growth from the primordial to the preovulatory stage) takes approximately 175 days in women (Gougeon, 1986; Wallace \& Kelsey, 2010) and 170 days in ewes (Cahill \& Mauleon, 1980; Bartlewski et al., 2011).

The primordial follicles, as well as the oocytes contained within, have similar diameters in both ewes and women, as depicted on Table 1 . The oocyte nucleus is relatively large in both species and occupies a central position, clearly showing its nucleolus. In contrast, primary and secondary follicles and their corresponding oocytes are larger in sheep than in women (Table 1 ).

Granulosa cell numbers increase, as well as the size and protein content of the oocyte, and formation of the basal lamina and zona pellucida layers denote secondary follicle formation (van Den Hurk \& Zhao, 2005). As shown on Table 1, ewe secondary follicles and their respective oocytes are larger than those of women. Secondary follicles are also observed in fetal ovaries, when the outer theca cells form from the interstitial stroma (van Den Hurk \& Zhao, 2005). In contrast, the inner theca cells are defined after the follicles develop four or more layers of granulosa cells (Lucci et al., 2001).

With the continuous growth of secondary follicles and the organization of granulosa cells into various layers, a cavity filled with fluid is formed, denoted as the antrum. From this stage, follicles are termed tertiary, or antral, and their diameters increase considerably due to oocyte growth, the multiplication of granulosa cells and the increase in antral cavity fluid (Mcgee \& Hsueh, 2000; Bartlewski et al., 2011).

With continuing growth and development, one or two antral follicles can potentially differentiate to become a Graafian, or preovulatory follicle. In response to the preovulatory gonadotropin surge occurring in each reproductive cycle, the Graafian follicle ovulates to release the mature oocyte ready to be potentially fertilized. However, throughout antral development, the majority of follicles undergo degeneration or atresia - the process responsible for the depletion of most of the ovarian follicles present in the ovary (Mcgee \& Hsueh, 2000; Balasch et al., 2010; Bartlewski et al., 2011).

Sheep ovaries as a model for fertility preservation studies in women

Many variables can affect ovarian tissue viability during vitrification, such as the cryoprotectant type or concentration, cell exposure duration, tissue fragment size, cooling device, and speed of cooling. These variable effects must be exhaustively evaluated to maximize current procedures.

As previously mentioned, the detailed study of human female ovarian tissues is not feasible. Therefore, as a general rule, animal models should be biochemically, physiologically and anatomically comparable with human ovarian structures; for instance, ovary size, stroma layer thickness, ovulations per cycle, and estrous cycle (Vandeberg, 2004; Gerritse et al., 2008). Although there is no animal model that is a perfect human model, studies completed in bovines, pigs, equines, non-human primates, and ovines have provided tremendous amounts of valuable information that has been utilized in human medicine

With cow ovaries being easily accessible from abattoirs, bovine physiological functions are well documented. (Lavranos et al., 1994; Yang \& Fortune, 2006; Irving-Rodgers et al., 2006). However, bovine ovaries are larger than the ovaries from women and the stromal tissue is much thicker (Gerritse et al., 2008).

Swine ovary size (approximately $7.3 \mathrm{~cm} 3$; Gerritse et al., 2008) is similar to that of women's ovaries $(6.5 \mathrm{~cm} 3$; Munn et al., 1986) but the sow is a poly-ovulatory species (Soede et al., 2011). In fact, the sow often ovulates more than ten oocytes per estrus. In addition, the large lipid content within swine oocytes impairs proper vitrification. A detailed study conducted on both cows and sows demonstrated that the particularities in their ovarian structures make them not ideal species to be used as a model for women (Gandolfi et al., 2006).

The follicular fluid from human and mare dominant follicle contains greater estradiol and progesterone concentrations and lower androstenedione concentrations when compared to subordinate follicles. Similarities in follicular wave development in both species, as well as other features, have provided reasons for utilizing the mare as an additional model for studying ovarian follicular development in women (Schneyer et al., 2000; Donadeu \& Ginther, 2002; Baerwald et al., 2012).

Non-human primates, like Rhesus macaques, have menstrual cycles that are analogous to women in duration and both steroid and protein hormone profiles. Anatomical similarities also exist when comparing oocytes between humans and non-human primates. Yet, the monkey mod-

Table 1. Folliculogenesis features in sheep and women

\begin{tabular}{|c|c|c|c|}
\hline & Sheep & Women & References \\
\hline Primordial follicles & $40.8(28.1-60.5) \mu \mathrm{m}$ & $35.4(29.2-41.6) \mu \mathrm{m}$ & $\begin{array}{c}\text { Lundy et al., } 1999 ; \\
\text { Gougeon \& Chainy, } 1987\end{array}$ \\
\hline Oocytes from primordial follicles & $34.6(22.8-52.3) \mu \mathrm{m}$ & $32.1(26.1-38.1) \mu \mathrm{m}$ & $\begin{array}{c}\text { Lundy et al., 1999; } \\
\text { Gougeon \& Chainy, } 1987\end{array}$ \\
\hline Primary follicles & $75.2(49.7-118.2) \mu \mathrm{m}$ & $46.0(39.8-52.2) \mu \mathrm{m}$ & $\begin{array}{c}\text { Lundy et al., 1999; } \\
\text { Gougeon \& Chainy, } 1987\end{array}$ \\
\hline $\begin{array}{l}\text { Oocytes from primary } \\
\text { follicles }\end{array}$ & $52.1(31.0-80.0) \mu \mathrm{m}$ & $32.6(27.7-37.5) \mu \mathrm{m}$ & $\begin{array}{c}\text { Lundy et al., 1999; } \\
\text { Gougeon \& Chainy, } 1987\end{array}$ \\
\hline Secondary follicles & $194.1(164.2-256.3) \mu \mathrm{m}$ & $77.2(66.3-88.1) \mu \mathrm{m}$ & $\begin{array}{c}\text { Lundy et al., 1999; } \\
\text { Gougeon \& Chainy, } 1987\end{array}$ \\
\hline Oocytes from secondary follicles & $72.9(40.6-92.0) \mu \mathrm{m}$ & $47.8(35.8-59.8) \mu \mathrm{m}$ & $\begin{array}{c}\text { Lundy et al., 1999; } \\
\text { Gougeon \& Chainy, } 1987\end{array}$ \\
\hline $\begin{array}{l}\text { Ovaries length, width and } \\
\text { thickness }\end{array}$ & $1.7 \times 1.2 \times 1 \mathrm{~cm}$ & $3 \times 1.5-2 \times 1 \mathrm{~cm}$ & $\begin{array}{l}\text { Mohammadpour, 2007; } \\
\text { Gartner; Hiatt, } 2003\end{array}$ \\
\hline Folliculogenesis duration & Approximately 170 days & More than 200 days & $\begin{array}{c}\text { Cahill \& Mauleon, 1980; } \\
\text { Gougeon, } 1986\end{array}$ \\
\hline
\end{tabular}


el also has limits that must be considered. For example, a limited number of laboratories work with monkeys and there are ethical restrictions over the use of such highly sentient animals in biomedical research (Wolf et al., 2008).

However, ewe ovarian cortex has structure that is similar to ovaries in women (Munn et al., 1986, Gerritse et al., 2008). Sheep, like women, have an ovarian stroma rich in collagen, mainly located around the primordial follicles. These follicles are generally found in large clusters that represent the follicular reserve pool (Arav et al., 2005). It should be emphasized that the cryopreservation of either cortex pieces or the entire ewe ovary is being closely studied because of the extensive knowledge about their ovarian physiology. In addition, ewe ovarian endocrine function after auto-transplantation has been studied for more than 40 years (Goding et al., 1967). Because of the ovarian similarities between this species and women, the first publication of a human birth after cryopreserved ovarian tissue transplantation (Donnez et al., 2004) was based on a protocol developed and tested using sheep as a model (Gosden et al., 1994). However, it is still necessary to conduct further comparative studies of human and ewe ovaries as they are not identical and have subtle physiological differences.

\section{Ovarian tissue cryopreservation}

Hundreds of immature oocytes inside preantral follicles are located in the ovarian cortex and can be cryopreserved in situ, i.e., enclosed within the ovarian tissue. Immature oocytes within preantral follicles are normally more resistant to cryopreservation than mature oocytes. This is due to multiple factors such as the small size of the oocyte, low metabolic rate, cell cycle stage (quiescent or in prophase I), as well as fewer supporting cells, cortical granules, and the smaller quantity of intracytoplasmic lipids (Shaw et al., 2000; Kagawa et al., 2009).

The advantages of ovarian cortex cryopreservation, in addition to the large number of follicles, is that the material can be obtained regardless of the age or phase of the menstrual or estrous cycle. Moreover, this process involves fewer ethical and social questions than the cryopreservation of embryos, especially when applied to the human species (Shaw et al., 2000). This characteristic is extremely pertinent for human assisted reproduction, especially for women who must start cancer treatment immediately. Ovarian tissue cryopreservation, as mentioned early, is also an alternative for girls who have not yet reached puberty or women who do not have a partner for the donation of male gametes (Wallace et al., 2005). Preantral follicle oocytes are more resistant to cryopreservation in comparison to mature oocytes (Shaw et al., 2000; Kagawa et al., 2009). In fact, the transplantation of frozen-thawed ovarian tissue or the isolation of their enclosed preantral follicles for further in vitro maturation represent a promising alternative to female fertility restoration, specifically in women that require immediate therapy or to pre-pubertal girls (Woodruff et al., 2009).

The transplantation of frozen-thawed tissue has been successfully utilized, with reports of 30 human births (Donnez \& Dolmans, 2013). The in vitro culture of ovarian follicles may be more viable since it eliminates the possibility of reintroduction of cancer cells back into the patient (Donnez et al., 2011). Although slow freezing has been successfully utilized for several years, the technique has some disadvantages compared to vitrification (Amorim et al., 2011a). The major disadvantage is ice formation during slow freezing, which results in cell structure damage. Since vitrification uses rapid cooling that results in solidification without crystallization, ice formation is prevented (Bagchi et al., 2008). Vitrification of ovarian tissue has been investigated in a variety of species by using several protocols, as well as different tissue sizes (fragments, hemi-ovaries or even whole ovaries).

Tissue cryopreservation is substantially different from the cryopreservation of cells in suspension, such as isolated preantral follicles. Several cell types within a tissue contribute to its complex final physiological function and the survival of each cell type after cryopreservation is critical. Ovarian stromal tissue is very rich in regards to both cell number and variety. Accordingly, extra- and intracellular ice formation can easily damage these cells, hindering cellular communication needed for the resumption of appropriate tissue function after cryopreservation (Amorim et al., 2011a).

An alternative to reduce injuries caused by the ice formation would be the cryopreservation of preantral follicles isolated from ovarian tissue, since this system utilizes follicles that are removed from surrounding tissue (Amorim et al., 2011a). When the follicles are cryopreserved separately from ovarian tissue, they have the advantage of facing no risks of damage caused by ischemia and revascularization and greater facility of cryoprotectant perfusion due to the absence of tissue barriers. This technique also allows for the possibility of individual follicle monitoring during the procedures of in vitro culture (Amorim et al., 2011a). Vanacker et al. (2013) evaluated the survival and growth potential of human preantral follicles isolated before and after cryopreservation. Researchers reported that human preantral follicles can be successfully cryopreserved prior to or after isolation without impairing their ability to survive and grow in vitro. Since the preservation of preantral follicles enclosed in ovarian tissue via the vitrification method have resulted in positive outcomes, (Bordes et al., 2005; Lornage et al., 2006; Wang et al., 2011) we will describe here reports concerning ewe and human ovarian tissue cryopreserved by vitrification.

\section{Advances in ovarian tissue vitrification in sheep}

One of the first studies with sheep ovarian vitrified tissue utilized a vitrification solution originally tested in cow oocytes; a solution consisting of ethylene glycol (EG), fetal bovine serum (FBS), polyvinylpyrrolidone and trehalose. This solution enabled the vitrification of immature oocytes in ovarian tissue, as well as their retrieval and development during in vitro maturation up to the second meiotic division. In this study, the percentage of oocytes matured in vitro after vitrification was similar to non-cryopreserved oocytes (Al-aghbari \& Menino, 2002).

Courbiere et al. (2005) demonstrated for the first time the possibility to maintain primordial follicle viability and morphology after sheep whole ovary vitrification, a fact that had been only demonstrated before in mice. In that study, two different vitrification solutions (VS) were used. One called VS1 and the other VS4, consisting of dimethylsulfoxide (DMSO), acetamide, polyethylene glycol, and propanodiol (PROH), or DMSO, formamide and $\mathrm{PROH}$, respectively. VS1 was described by Rall \& Fahy (1985) and utilized in murine embryos, while VS4 was first used for rabbit kidney vitrification (Kheirabadi \& Fahy, 2000).

Ewe research on sheep progressed considerably with the publication of two successful reports, both after an orthotopic autotransplant of vitrified ovarian tissue in VS1, a solution previously described by Rall \& Fahy in 1985 (Bordes et al., 2005; Lornage et al., 2006) (Table 2 ). The first of the two cited studies used six animals in which the cortical tissues were vitrified and later transplanted. Endocrine ovarian function resumption was detected in all animals four months after the transplant, with three of these ewes successfully producing offspring after natural mating (Bordes et al., 2005). In the second study, the orthotopic autotransplant of vitrified ovarian fragments resulted in three pregnancies with 
Table 2. Advances in sheep ovarian tissue vitrification

\begin{tabular}{|c|c|c|c|c|}
\hline Reference & Tissue & $\begin{array}{l}\text { Vitrification } \\
\text { device }\end{array}$ & Vitrification solution & Main outcomes \\
\hline $\begin{array}{l}\text { Al-aghbari; } \\
\text { Menino, } 2002 .\end{array}$ & $\begin{array}{l}\text { Ovarian fragments } \\
(0.5 \mathrm{~cm} \times 0.5 \mathrm{~cm})\end{array}$ & $\begin{array}{l}\text { Tissue dropped } \\
\text { on the surface } \\
\text { of a steel cube } \\
\text { cooled by } \mathrm{LN}_{2} \\
\end{array}$ & $\begin{array}{l}\text { 35\% EG, 5\% polyvinylpyrroli- } \\
\text { done, } 0.4 \mathrm{~mol} / \mathrm{L} \text { trehalose and } \\
20 \% \text { FBS }\end{array}$ & $\begin{array}{l}\text { Maintenance of oocyte recovery } \\
\text { rate and percentage of oocytes } \\
\text { developing to metaphase }\end{array}$ \\
\hline $\begin{array}{l}\text { Bordes } \\
\text { et al., } 2005 .\end{array}$ & $\begin{array}{l}\text { Ovarian fragments } \\
(1 \mathrm{~mm} \times 2 \mathrm{~cm} \times \\
1 \mathrm{~cm})\end{array}$ & $\begin{array}{l}\text { Cryogenic vials } \\
\text { plunged directly } \\
\text { into } \mathrm{LN}_{2}\end{array}$ & $\begin{array}{l}2.62 \mathrm{~mol} / \mathrm{L} \text { DMSO, } 2.60 \mathrm{~mol} / \mathrm{L} \\
\text { acetamide, } 1.31 \mathrm{~mol} / \mathrm{L} 1.2 \\
\text { PROH, and } 0.0075 \mathrm{~mol} / \mathrm{L} \\
\text { PEG (gradual dehydration in: } \\
12.5 \%, 25 \%, 50 \% \text { and } 100 \% \\
\text { of vitrification solution) }\end{array}$ & $\begin{array}{l}\text { Pregnancies occurred after } \\
\text { ovarian cortex autotransplanta- } \\
\text { tion, } 4 \text { lambs were born }\end{array}$ \\
\hline $\begin{array}{l}\text { Courbiere } \\
\text { et al., } 2005 .\end{array}$ & $\begin{array}{l}\text { Whole ovaries with } \\
\text { vascular pedicle }\end{array}$ & $\begin{array}{l}\text { Samples plunged } \\
\text { directly into } \mathrm{LN}_{2}\end{array}$ & $\begin{array}{l}2.75 \mathrm{~mol} / \mathrm{L} \text { DMSO, } 2.76 \mathrm{~mol} / \mathrm{L} \\
\text { formamide, and } 1.97 \mathrm{~mol} / \mathrm{L} \\
\text { PROH (gradual dehydration } \\
\text { in: } 12.5 \%, 25 \%, 50 \% \text { and } \\
100 \% \text { of vitrification solution) }\end{array}$ & $\begin{array}{l}\text { Maintaining primordial follicle } \\
\text { viability comparable to the } \\
\text { fresh tissue }\end{array}$ \\
\hline $\begin{array}{l}\text { Courbiere } \\
\text { et al., } 2006 .\end{array}$ & Whole ovaries & $\begin{array}{l}\text { Ethyl vinyl ac- } \\
\text { etate cryobag } \\
\text { plunged into } \mathrm{LN}_{2}\end{array}$ & $\begin{array}{l}2.75 \mathrm{~mol} / \mathrm{L} \text { DMSO, } 2.76 \mathrm{~mol} / \mathrm{L} \\
\text { formamide, and } 1.97 \mathrm{~mol} / \mathrm{L} \\
\text { PROH (gradual dehydration } \\
\text { in: } 12.5 \%, 25 \%, 50 \% \text { an } \\
100 \% \text { of vitrification solution) }\end{array}$ & $\begin{array}{l}\text { Maintaining the aspect of the } \\
\text { ovarian vein identical to the } \\
\text { nonvitrified control }\end{array}$ \\
\hline $\begin{array}{l}\text { Lornage } \\
\text { et al., } 2006 .\end{array}$ & $\begin{array}{l}\text { Ovarian fragments } \\
\text { ( } 1 \mathrm{~mm} \text { thick and } \\
1 \mathrm{~cm}^{2} \text { surface) }\end{array}$ & $\begin{array}{l}\text { Cryotube plunged } \\
\text { into } \mathrm{LN}_{2}\end{array}$ & $\begin{array}{l}2.62 \mathrm{~mol} / \mathrm{L} \text { DMSO, } 2.60 \mathrm{~mol} / \mathrm{L} \\
\text { acetamide, } 1,31 \mathrm{~mol} / \mathrm{L} 1.2 \\
\mathrm{PROH} \text {, and } 0.0075 \mathrm{~mol} / \mathrm{L} \text { PEG }\end{array}$ & $\begin{array}{l}\text { Pregnancies occurred after } \\
\text { autotransplantation of vitrified } \\
\text { warmed ovarian cortex and } \\
\text { lambs were born }\end{array}$ \\
\hline $\begin{array}{l}\text { Baudot } \\
\text { et al., } 2007 .\end{array}$ & $\begin{array}{l}\text { Whole ovary with } \\
\text { blood vessels. }\end{array}$ & $\begin{array}{l}\text { Ethyl vinyl ac- } \\
\text { etate cryobag } \\
\text { plunged into } \mathrm{LN}_{2}\end{array}$ & $\begin{array}{l}2.75 \mathrm{~mol} / \mathrm{L} \text { DMSO, } 2.76 \\
\text { mol/L formamide and } 1.97 \\
\text { mol/L PROH (gradual de- } \\
\text { hydration in: } 12.5 \%, 25 \%, \\
50 \% \text { and } 100 \% \text { of vitrification } \\
\text { solution) }\end{array}$ & $\begin{array}{l}\text { Maintaining ovarian primordi- } \\
\text { al follicle density and follicle } \\
\text { membrane integrity similar to } \\
\text { the fresh tissue }\end{array}$ \\
\hline $\begin{array}{l}\text { Courbiere } \\
\text { et al., } 2009 .\end{array}$ & $\begin{array}{l}\text { Whole ovary with } \\
\text { blood vessels }\end{array}$ & $\begin{array}{l}\text { Ethyl vinyl ac- } \\
\text { etate cryobag } \\
\text { plunged into } \mathrm{LN}_{2}\end{array}$ & $\begin{array}{l}2.75 \mathrm{~mol} / \mathrm{L} \text { DMSO, } 2.76 \mathrm{~mol} / \mathrm{L} \\
\text { formamide, and } 1.97 \mathrm{~mol} / \mathrm{L} \\
\text { PROH (gradual dehydration } \\
\text { in: } 12.5 \%, 25 \%, 50 \% \text { and } \\
100 \% \text { of vitrification solution) }\end{array}$ & $\begin{array}{l}\text { One sheep recovered ovarian } \\
\text { endocrine function } 6 \text { months } \\
\text { after transplantation }\end{array}$ \\
\hline $\begin{array}{l}\text { Fathi } \\
\text { et al., } 2011 .\end{array}$ & $\begin{array}{l}\text { Ovarian fragments } \\
\left(1 \times 2 \times 2 \mathrm{~mm}^{3}\right)\end{array}$ & $\begin{array}{l}\text { Cryopin (sam- } \\
\text { ple adhered in a } \\
\text { needle) plunged } \\
\text { into } \mathrm{LN}_{2}\end{array}$ & $\begin{array}{l}60 \% \text { HTCM, } 15 \% \text { EG, } 15 \% \\
\text { DMSO, } 0.25 \mathrm{~mol} / \mathrm{L} \text { SUC and } \\
10 \% \text { HSA }\end{array}$ & $\begin{array}{l}\text { Maintaining intact antral folli- } \\
\text { cles using 2-step dehydration } \\
\text { protocol }\end{array}$ \\
\hline $\begin{array}{l}\text { Melo } \\
\text { et al., } 2011 .\end{array}$ & $\begin{array}{l}\text { Ovarian fragments } \\
\left(1 \mathrm{~mm}^{3}\right)\end{array}$ & $\begin{array}{l}\text { Solid-surface } \\
\text { plunged into } \mathrm{LN}_{2}\end{array}$ & $\begin{array}{l}40 \% \mathrm{EG}, 0.5 \mathrm{~mol} / \mathrm{L} \mathrm{SUC} \text { and } \\
50 \mu \mathrm{g} / \mathrm{mL} \mathrm{AA}\end{array}$ & $\begin{array}{l}\text { Maintaining follicular viability } \\
\text { rates similar to the fresh tissue } \\
\text { after } 5 \text { days of tissue culture }\end{array}$ \\
\hline $\begin{array}{l}\text { Lunardi } \\
\text { et al., } 2012 .\end{array}$ & $\begin{array}{l}\text { Ovarian fragments } \\
\left(3 \times 3 \times 1: 9 \mathrm{~mm}^{3}\right)\end{array}$ & $\begin{array}{l}\text { Macrotube } \\
\text { plunged into } \mathrm{LN}_{2}\end{array}$ & $\begin{array}{l}6 \mathrm{~mol} / \mathrm{L} \mathrm{EG}, 0.25 \mathrm{~mol} / \mathrm{L} \mathrm{SUC} \\
\text { and } 10 \% \mathrm{FCS}\end{array}$ & $\begin{array}{l}\text { Maintaining follicular viabili- } \\
\text { ty similar to the cultured non- } \\
\text { vitrified tissue after } 2 \text { days of } \\
\text { tissue culture }\end{array}$ \\
\hline $\begin{array}{l}\text { Torre } \\
\text { et al., } 2012 .\end{array}$ & Whole ovaries & $\begin{array}{l}\text { Ethyl vinyl } \\
\text { acetate cryobags } \\
\text { plunged into } \mathrm{LN}_{2}\end{array}$ & $\begin{array}{l}2.75 \mathrm{~mol} / \mathrm{L} \text { DMSO, } 2.76 \mathrm{~mol} / \mathrm{L} \\
\text { formamide and } 1.97 \mathrm{~mol} / \mathrm{L} \\
\text { PROH (gradual dehydration in: } \\
12.5 \%, 25 \%, 50 \% \text { and } 100 \% \\
\text { of vitrification solution) }\end{array}$ & $\begin{array}{l}\text { Significant reduction in ovarian } \\
\text { pedicle metabolism after } \\
\text { vitrification }\end{array}$ \\
\hline
\end{tabular}

Note: $\mathrm{LN}_{2}=$ Liquid nitrogen, $\mathrm{EG}=$ Ethylene glycol, FBS $=$ Fetal bovine serum, DMSO = Dimethylsulfoxyde, PROH =: Propylene glycol, PEG = Polyethylene glycol, HTCM = HEPES tissue culture medium, SUC = Sucrose, HSA = Human serum albumin, AA = Ascorbic acid, FCS $=$ Fetal calf serum. 
the production of four lambs (Lornage et al., 2006). Several other studies were conducted on the vitrification of sheep whole ovaries (Courbiere et al., 2006; 2009). Baudot et al. (2007) tested the VS4 solution previously described by Kheirabadi \& Fahy (2000) for whole ovary vitrification and obtained reasonable rates of follicular viability $(61.4 \pm 2.2 \%)$ and normal morphology $(48 \pm 3.8 \%)$. Also in 2007, Courbiere et al. demonstrated that the reestablishment of hormone production was also maintained after the transplant of whole vitrified ovaries.

Fathi et al. (2011) compared vitrification techniques using two or four solutions with increasing EG and DMSO concentrations. Morphological evaluation was performed to quantify follicles in different developmental phases (primordial, primary, secondary, and antral) and differences in survival rates were observed among the different follicular classes. In general, vitrification performed with only two solutions yielded positive results with a lower incidence of cell death, as evaluated by the TUNEL technique. The vitrification technique used was called "cryopin" since ovarian fragments are picked up with an insulin needle, immersed in liquid nitrogen and then stored in cryotubes.

Although several studies have been conducted to develop a cryoprotectant, as well as a satisfactory vitrification technique (Fathi et al., 2011; Lunardi et al., 2012), until now, there has been no consensus regarding the best solution or even vitrification technique for sheep ovarian tissue. The few births reported in the literature thus far originated from ovarian tissue vitrified in the VS1 solution with direct immersion of ovarian tissue in liquid nitrogen, which was stored in cryotubes (Bordes et al., 2005; Lornage et al., 2006).

Advances in the in vitro culture of vitrified sheep ovarian tissue

Although the combination of vitrification and in vitro culture has resulted in the birth of mice (Hasegawa et al., 2006; Wang et al., 2011), there is no similar success documented in sheep.

The few studies conducted so far have demonstrated that the addition of antioxidant agents like ascorbic acid, considerably improves tissue viability after in vitro culture, both in the culture medium and in the vitrification solution. This may be due to their role in assisting collagen biosynthesis. It was also demonstrated that the vitrification solution containing EG associated with ascorbic acid promoted better results than the association with DMSO (Melo et al., 2011). The viability of ovarian vitrified tissue analyzed after $48 \mathrm{~h}$ of in vitro culture was similar to the fresh control with the use of a vitrification solution containing EG (6 M), fetal calf serum (FCS) $(10 \%)$ and sucrose (0.25 M) (Lunardi et al., 2012).

\section{Advances in ovarian tissue vitrification in women}

Pioneering studies using vitrification methods were conducted on fetal ovaries obtained from elective abortions in China (Zhang et al., 1995) (Table 3). Despite relevant results obtained in this study, only years later other researchers performed vitrification in the women ovarian tissue.

After the vitrification of women's ovaries, ovarian follicles and the stromal cells were better morphologically preserved than in the slow-freezing group (Chang et al., 2011).

Rahimi et al. (2003) evaluated different vitrification protocols and reported that women's ovarian tissues that were cooled rapidly did not have statistically increased apoptosis compared with fresh controls. A later study demonstrated that both oocyte viability and granulosa cell proliferation were also maintained after vitrification (Kagawa et al., 2009). Although increased success has been ob- tained using vitrification as a viable method for cryopreserving ovarian tissue, studies have shown that follicular apoptosis (Zhou et al., 2010) and disrupted morphology (Xiao et al., 2010, Amorim et al., 2011b) are still higher than those found in fresh tissue.

Ovary vitrification in women, combined with xenotransplantation is an ample field for research, but few studies have investigated xenografting after warmed, post-vitrified human ovarian tissue (Rahimi et al., 2004; Rahimi et al., 2009; Rahimi et al., 2010; Amorim et al., 2012). Rahimi et al. (2004) observed no increase in necrotic area proportion in the human vitrified-thawed ovarian tissue after 42 days of subcutaneous xenotransplantation in severe combined immunodeficiency (SCID) mice compared to fresh or slow human cryopreserved ovarian tissue. In contrast, the same team later reported that xenografts of vitrified-thawed human ovarian tissue in SCID mice after 30 days had a significantly greater amount of apoptotic cells, when compared to slow frozen (Rahimi et al., 2009).

Angiogenesis, the development of new blood vessels from preexisting ones, is delayed after tissue transplantation, triggering ischemia and hypoxia, which results in massive follicular loss until vascularization is reestablished. After human ovarian tissues were vitrified, thawed, and xenotransplanted for 30 days in SCID mice, the tissues were observed to have vascularization similar to tissues undergoing a similar process, but had been previously frozen (Rahimi et al., 2010). Amorim et al. (2012) observed a lower percentage of DNA damage in follicles within vitrified-thawed human ovarian tissue after 7 days of xenotransplantation in SCID mice. Since, in addition to these data, a single birth after ovarian vitrification was reported in women (Kawamura et al., 2013), further research should be directed to this area to find an ideal protocol to vitrify ovarian tissue from women.

Advances in the in vitro culture of vitrified women ovarian tissue

Since the beginning of the last decade, several studies have shown that the association of vitrification and in vitro culture can be successfully applied to human ovarian tissue, promoting stroma (Keros et al., 2009) and follicle morphology (Lee et al., 2000) preservation.

Follicle morphology has been evaluated after vitrified-thawed ovarian tissue in vitro culture for short or long periods (between one and 21 days) (Salehnia et al., 2012; Isachenko et al., 2003) and has been reported that it is possible to preserve morphology similar to that of fresh tissue (Salehnia et al., 2012; Isachenko et al., 2008; Lee et al., 2000; Isachenko et al., 2003) similar to slow freezing tissue (Huang et al., 2008), or even better than slow freezing tissue (Keros et al., 2009).

Li et al. (2007) found no significant differences in the proportion of morphologically normal primordial and primary follicles after in vitro culture (14 days). Ultra-strutural chromatin features of oocytes and follicular cells were normal after vitrified-thawed ovarian tissue and in vitro culture for one day, which was similar to the fresh tissue controls (Salehnia et al., 2012). These authors also demonstrated that the use of a vitrification solution based on the content of EG or a mixture of EG and DMSO did not affect primordial or primary follicle morphology after one day of tissue culture.

Follicle viability has been preserved so that it is similar to that of fresh tissue after vitrified-thawed ovarian tissue and in vitro culture for 14 days (Lee et al., 2000). Isachenko et al. (2006) showed that the in vitro culture of vitrified tissue in large volumes of culture medium $(30 \mathrm{ml})$ under constant shaking guaranteed an increase in follicular viability. These results suggest that the combination of these procedures favors the maintenance of ovarian function. 
Table 3. Advances in women ovarian tissue vitrification

\begin{tabular}{|c|c|c|c|c|}
\hline Reference & Tissue & $\begin{array}{c}\text { Vitrification } \\
\text { device }\end{array}$ & Vitrification solution & Main outcomes \\
\hline $\begin{array}{l}\text { Zhang } \\
\text { et al., } 1995 .\end{array}$ & $\begin{array}{l}\text { Fragments of fetal } \\
\text { ovary }\left(0.5-1 \mathrm{~mm}^{3}\right)\end{array}$ & $\begin{array}{l}\text { Plastic cryo straws } \\
\text { directly plunged into } \\
\mathrm{LN}_{2}\end{array}$ & $\begin{array}{l}4.2 \mathrm{~mol} / \mathrm{L} \text { DMSO, } 0.35 \\
\mathrm{~mol} / \mathrm{L} \mathrm{SUC} \text { and } 15 \mathrm{mg} / \\
\mathrm{ml} \mathrm{BSA}\end{array}$ & $\begin{array}{l}\text { Maintaining oocyte quality } \\
\text { similar to the fresh tissue af- } \\
\text { ter } 40 \text { days of tissue culture }\end{array}$ \\
\hline $\begin{array}{l}\text { Isachenko } \\
\text { et al., } 2003 .\end{array}$ & $\begin{array}{l}\text { Ovarian fragments } \\
(0.8 \mathrm{~mm} \times 0.8 \mathrm{~mm} \times \\
0.8 \mathrm{~mm})\end{array}$ & $\begin{array}{l}\text { Straws or grids } \\
\text { directly plunged into } \\
\mathrm{LN}_{2}\end{array}$ & $\begin{array}{l}40 \% \text { EG, } 0.35 \mathrm{~mol} / \mathrm{L} \\
\text { SUC and } 5 \% \text { egg yolk } \\
\text { extract }\end{array}$ & $\begin{array}{l}\text { Maintaining the proportion } \\
\text { of morphologically normal } \\
\text { follicles similar to the fresh } \\
\text { tissue }\end{array}$ \\
\hline $\begin{array}{l}\text { Rahimi } \\
\text { et al., } 2003 .\end{array}$ & $\begin{array}{l}\text { Ovarian fragments } \\
\left(1 \pm 0.5 \mathrm{~mm}^{3}\right)\end{array}$ & $\begin{array}{l}\text { Straws, grids or } \\
\text { metal filings directly } \\
\text { plunged into LN2 or } \\
\text { into nitrogen vapor }\end{array}$ & $\begin{array}{l}40 \% \text { EG, } 0.35 \mathrm{~mol} / \mathrm{L} \\
\text { SUC and } 10 \% \text { egg yolk } \\
\text { extract or } 40 \% \mathrm{EG}, 18 \% \\
\text { Ficoll and } 0.35 \mathrm{~mol} / \mathrm{L} \\
\text { SUC }\end{array}$ & $\begin{array}{l}\text { Cooling using nitrogen vapor } \\
\text { resulted in significantly } \\
\text { elevated ROS levels and } \\
\text { apoptosis after warming }\end{array}$ \\
\hline $\begin{array}{l}\text { Rahimi } \\
\text { et al., } 2004 .\end{array}$ & $\begin{array}{l}\text { Ovarian fragments } \\
(0.5 \times 1.0 \times 4.0 \mathrm{~mm})\end{array}$ & $\begin{array}{l}\text { Straws directly } \\
\text { plunged into } \mathrm{LN}_{2}\end{array}$ & $\begin{array}{l}25 \% \text { Glycerol, } 25 \% \\
\text { EG, } 15 \% \text { FCS and } 1 \% \\
\text { Supercool X-100 (last } \\
\text { solution from three } \\
\text { steps) }\end{array}$ & $\begin{array}{l}\text { No rise in the proportion } \\
\text { of necrotic areas after } 42 \\
\text { days of xenotransplantation } \\
\text { compared to fresh or slow } \\
\text { cryopreserved tissue }\end{array}$ \\
\hline $\begin{array}{l}\text { Gandolfi } \\
\text { et al., } 2006 .\end{array}$ & $\begin{array}{l}\text { Ovarian fragments } \\
\left(1 \mathrm{~mm}^{3}\right)\end{array}$ & $\begin{array}{l}\text { Straws directly } \\
\text { plunged into } \mathrm{LN}_{2}\end{array}$ & $\begin{array}{l}3.58 \mathrm{~mol} / \mathrm{L} \mathrm{EG}, 2.82 \\
\mathrm{~mol} / \mathrm{L} \mathrm{DMSO} \text { and } 20 \% \\
\mathrm{FCS}\end{array}$ & $\begin{array}{l}\text { The addition of DMSO to the } \\
\text { vitrification solution reduced } \\
\text { primary follicles cryoinjuries }\end{array}$ \\
\hline $\begin{array}{l}\text { Isachenko } \\
\text { et al., } 2006 .\end{array}$ & $\begin{array}{l}\text { Ovarian fragments } \\
(1 \times 1 \times 5 \mathrm{~mm})\end{array}$ & $\begin{array}{l}\text { Cryovials directly } \\
\text { plunged into } \mathrm{LN}_{2}\end{array}$ & $\begin{array}{l}20 \% \text { DMSO, } 40 \% \text { EG } \\
\text { and } 10 \% \text { SSS (last solu- } \\
\text { tion from two steps) }\end{array}$ & $\begin{array}{l}\text { Morphologically normal } \\
\text { follicles were observed when } \\
\text { vitrified ovarian tissue was } \\
\text { cultured for } 14 \text { days in a } \\
\text { large volume of culture } \\
\text { medium in combination with } \\
\text { stirring }\end{array}$ \\
\hline $\begin{array}{l}\mathrm{Li} \\
\text { et al., } 2007 .\end{array}$ & $\begin{array}{l}\text { Ovarian fragments } \\
(5 \times 1 \times 1 \mathrm{~mm})\end{array}$ & $\begin{array}{l}\text { Minimum drop size } \\
\text { directly plunged into } \\
\mathrm{LN}_{2}\end{array}$ & $\begin{array}{l}2 \mathrm{~mol} / \mathrm{L} \text { DMSO, } 2 \mathrm{~mol} / \mathrm{L} \\
\mathrm{PROH}, 0.2 \mathrm{~mol} / \mathrm{L} \mathrm{SUC} \\
\text { and } 12 \% \mathrm{HSA}\end{array}$ & $\begin{array}{l}\text { Maintaining estradiol and } \\
\text { progesterone production } \\
\text { during } 14 \text { days of tissue cul- } \\
\text { ture similar to the slow-fro- } \\
\text { zen tissue }\end{array}$ \\
\hline $\begin{array}{l}\text { Huang } \\
\text { et al., } 2008 .\end{array}$ & $\begin{array}{l}\text { Ovarian fragments } \\
(5 \times 1 \times 1 \mathrm{~mm})\end{array}$ & $\begin{array}{l}\text { Solid-surface } \\
\text { vitrification }\end{array}$ & $\begin{array}{l}20 \% \text { DMSO, } 20 \% \text { EG, } \\
25 \mathrm{mg} / \mathrm{ml} \mathrm{HSA} \text { (gradual } \\
\text { dehydration in: } 25 \% \text {, } \\
50 \%, 75 \% \text { and } 100 \% \text { of } \\
\text { vitrification solution) }\end{array}$ & $\begin{array}{l}\text { Maintaining the percentage } \\
\text { of intact primordial follicles } \\
\text { and secretion of estradiol and } \\
\text { progesterone within } 10 \text { days } \\
\text { of tissue culture similar to } \\
\text { the slow-frozen tissue }\end{array}$ \\
\hline $\begin{array}{l}\text { Isachenko } \\
\text { et al., } 2008 .\end{array}$ & $\begin{array}{l}\text { Ovarian fragments } \\
\text { (about } 1 \mathrm{~mm}^{3} \text { ) }\end{array}$ & $\begin{array}{l}\text { Droplet directly } \\
\text { plunged into } \mathrm{LN}_{2}\end{array}$ & $\begin{array}{l}2.62 \mathrm{~mol} / \mathrm{L} \text { DMSO, } 2.6 \\
\text { mol/L acetamide, } 1.31 \\
\text { mol/L PROH and } 0.0075 \\
\text { mol/L PEG (gradual } \\
\text { dehydration in: } 25 \% \text {, } \\
50 \%, 75 \% \text { and } 100 \% \text { of } \\
\text { vitrification solution) }\end{array}$ & $\begin{array}{l}\text { Maintaining normally devel- } \\
\text { oped follicles similar to the } \\
\text { fresh tissue after } 12 \text { days of } \\
\text { tissue culture }\end{array}$ \\
\hline $\begin{array}{l}\text { Wang } \\
\text { et al., } 2008 .\end{array}$ & $\begin{array}{l}\text { Ovarian fragments } \\
\left(\sim 1-2.5 \mathrm{~mm}^{2}\right)\end{array}$ & $\begin{array}{l}\text { Needle directly } \\
\text { plunged into } \mathrm{LN}_{2}\end{array}$ & $\begin{array}{l}15 \% \text { EG, } 15 \% \text { DMSO } \\
\text { and } 0.5 \mathrm{~mol} / \mathrm{L} \text { SUC }\end{array}$ & $\begin{array}{l}\text { Maintaining the ultrastruc- } \\
\text { ture of stromal cells better } \\
\text { than the slow-freezing or the } \\
\text { dropping vitrification group }\end{array}$ \\
\hline $\begin{array}{l}\text { Kagawa } \\
\text { et al., } 2009 .\end{array}$ & $\begin{array}{l}\text { Ovarian fragments } \\
(1 \times 10 \times 10 \mathrm{~mm})\end{array}$ & $\begin{array}{l}\text { Metal strip plunged } \\
\text { into } \mathrm{LN}_{2} \\
\text { (Cryotissue) }\end{array}$ & $\begin{array}{l}20 \% \mathrm{EG}, 20 \% \mathrm{DMSO}, \\
0.5 \mathrm{~mol} / \mathrm{I} \mathrm{SUC}\end{array}$ & $\begin{array}{l}\text { Maintenance of oocyte viabil- } \\
\text { ity similar to the fresh tissue }\end{array}$ \\
\hline $\begin{array}{l}\text { Keros } \\
\text { et al., } 2009 .\end{array}$ & $\begin{array}{l}\text { Ovarian fragments } \\
(1 \times 1-2 \times 5-8 \mathrm{~mm})\end{array}$ & $\begin{array}{l}\text { Cryo straws } \\
\text { (Hand-cut straw) }\end{array}$ & $\begin{array}{l}1.4 \mathrm{~mol} / \mathrm{L} \text { DMSO, } 1.5 \\
\mathrm{~mol} / \mathrm{L} \text { EG, } 1.5 \mathrm{PROH}, 10 \\
\mathrm{mg} / \mathrm{mL} \text { HSA, and } 10 \% \\
\text { PVP (last solution from } \\
\text { three steps) }\end{array}$ & $\begin{array}{l}\text { Preservation of ovarian stro- } \\
\text { ma morphology after } 1 \text { day } \\
\text { of tissue culture better than } \\
\text { slow freezing procedure }\end{array}$ \\
\hline
\end{tabular}




\begin{tabular}{|c|c|c|c|c|}
\hline $\begin{array}{l}\text { Rahimi } \\
\text { et al., } 2010 .\end{array}$ & $\begin{array}{l}\text { Ovarian fragments } \\
(\sim 0.5 \times 1 \times 1 \mathrm{~mm})\end{array}$ & $\begin{array}{l}\text { Droplet directly } \\
\text { plunged into } \mathrm{LN}_{2}\end{array}$ & $\begin{array}{l}2.62 \mathrm{~mol} / \mathrm{L} \text { DMSO, } 2.6 \\
\mathrm{~mol} / \mathrm{L} \text { acetamide, } 1.31 \\
\mathrm{~mol} / \mathrm{L} \text { PROH and } 0.0075 \\
\text { mol/L PEG (gradual de- } \\
\text { hydration in: } 25 \%, 50 \% \text {, } \\
75 \% \text { and } 100 \% \text { of solu- } \\
\text { tion) }\end{array}$ & $\begin{array}{l}\text { Maintaining the revascular- } \\
\text { ization of ovarian tissue sim- } \\
\text { ilar to the frozen tissue after } \\
30 \text { days of xenotransplanta- } \\
\text { tion }\end{array}$ \\
\hline $\begin{array}{l}\text { Xiao } \\
\text { et al., } 2010 .\end{array}$ & $\begin{array}{l}\text { Ovarian fragments } \\
\left(\sim 2-3 \mathrm{~mm}^{2}\right)\end{array}$ & $\begin{array}{l}\text { Needle directly } \\
\text { plunged into } \mathrm{LN}_{2}\end{array}$ & $\begin{array}{l}2.15 \mathrm{~mol} / \mathrm{L} \text { EG, } 1.69 \\
\mathrm{~mol} / \mathrm{L} \text { DMSO and } 0.5 \\
\mathrm{~mol} / \mathrm{L} \text { SUC (last solution } \\
\text { from two steps) }\end{array}$ & $\begin{array}{l}\text { The use of needle immersed } \\
\text { vitrification method enabled } \\
\text { the use of lower cryopro- } \\
\text { tectant concentration leading } \\
\text { to improvements in tissue } \\
\text { cryopreservation }\end{array}$ \\
\hline $\begin{array}{l}\text { Zhou } \\
\text { et al., } 2010 .\end{array}$ & $\begin{array}{l}\text { Ovarian fragments } \\
(1 \times 1 \times 1 \mathrm{~mm})\end{array}$ & $\begin{array}{l}\text { Direct cover } \\
\text { vitrification (DCV) } \\
\text { or conventional } \\
\text { vitrification }(\mathrm{CV}) \\
\end{array}$ & $\begin{array}{l}15 \% \text { EG and } 15 \% \text { DMSO } \\
\text { or } 20 \% \text { EG and } 20 \% \\
\text { DMSO }\end{array}$ & $\begin{array}{l}\text { DCV showed a higher per- } \\
\text { centage of normal follicles } \\
\text { and promoted less apoptotic } \\
\text { cells compared with CV }\end{array}$ \\
\hline $\begin{array}{l}\text { Amorim } \\
\text { et al., 2011b. }\end{array}$ & $\begin{array}{l}\text { Ovarian fragments } \\
\left(1 \mathrm{~mm}^{3}\right)\end{array}$ & $\begin{array}{l}\text { Droplet directly } \\
\text { plunged into } \mathrm{LN}_{2}\end{array}$ & $\begin{array}{l}38 \% \text { EG, } 0.5 \mathrm{~mol} / \mathrm{L} \\
\text { trehalose, } 6 \% \text { FBS in } \\
\text { MEM-GlutaMAX at } 10 \%\end{array}$ & $\begin{array}{l}\text { Maintaining a high percent- } \\
\text { age of normal follicles than } \\
\text { solid-surface vitrification }\end{array}$ \\
\hline $\begin{array}{l}\text { Salehnia } \\
\text { et al., } 2012 .\end{array}$ & $\begin{array}{l}\text { Ovarian fragments } \\
\left(1-1.5 \mathrm{~mm}^{3}\right)\end{array}$ & $\begin{array}{l}\text { Cryovials or cryo- } \\
\text { vials pre-cooled to } \\
0^{\circ} \mathrm{C} \text { put in nitrogen } \\
\text { vapour for } 30 \mathrm{~s} \text { and } \\
\text { then immersed } \mathrm{LN}_{2}\end{array}$ & $\begin{array}{l}40 \% \text { EG, } 30 \% \text { Ficoll, } \\
1 \mathrm{~mol} / \mathrm{S} \text { SUC and } 1.2 \% \\
\text { BSA or increasing } \\
\text { concentrations ( } 2.5 \% \text {, } \\
5 \% \text { and } 10 \%) \text { of DMSO, } \\
\text { PROH and EG with } \\
10 \% \text { HSA }\end{array}$ & $\begin{array}{l}\text { Maintenance of proportions } \\
\text { of normal follicles, DNA frag- } \\
\text { mentation and ultrastructural } \\
\text { characteristics similar to the } \\
\text { fresh tissue after } 1 \text { day of } \\
\text { ovarian cortex culture }\end{array}$ \\
\hline $\begin{array}{l}\text { Oktem } \\
\text { et al., } 2011 .\end{array}$ & $\begin{array}{l}\text { Ovarian fragments } \\
(0.25 \mathrm{~cm})\end{array}$ & $\begin{array}{l}\text { Tissue loaded into } \\
\text { vials and immersed } \\
\text { in LN2 }\end{array}$ & $\begin{array}{l}15 \% \mathrm{PROH}, 15 \% \mathrm{EG}, \\
0.2 \mathrm{~mol} / \mathrm{L} \text { SUC and } \\
10 \% \mathrm{HSA}\end{array}$ & $\begin{array}{l}\text { Maintaining estradiol pro- } \\
\text { duction similar to the slow- } \\
\text { frozen tissue after } 3 \text { days of } \\
\text { tissue culture }\end{array}$ \\
\hline $\begin{array}{l}\text { Amorim } \\
\text { et al., } 2012 .\end{array}$ & $\begin{array}{l}\text { Ovarian fragments } \\
(1.0 \times 1.0 \times 1.0 \mathrm{~mm})\end{array}$ & $\begin{array}{l}\text { Solid-surface vitrifi- } \\
\text { cation or open cryo } \\
\text { straws }\end{array}$ & $\begin{array}{l}20 \% \mathrm{DMSO}, 20 \% \text { EG } \\
\text { and } 25 \mathrm{mg} / \mathrm{mL} \mathrm{HSA} \text { or } \\
10 \% \mathrm{DMSO}, 26 \% \mathrm{EG} \text {, } \\
2.5 \% \mathrm{PVP}, 20 \mathrm{mg} / \mathrm{mL} \\
\mathrm{HSA} \text { and } 1 \mathrm{~mol} / \mathrm{L} \mathrm{SUC}\end{array}$ & $\begin{array}{l}\text { Percentage of follicles with } \\
\text { DNA damage lower than in } \\
\text { the slow-frozen tissue after } 7 \\
\text { days of xenotransplantation }\end{array}$ \\
\hline $\begin{array}{l}\text { Kawamura } \\
\text { et al., } 2013 .\end{array}$ & & & & Pregnancy and birth \\
\hline
\end{tabular}

Note: $\mathrm{LN}_{2}=$ liquid nitrogen, $\mathrm{DMSO}=$ Dimethylsulfoxide, $\mathrm{SUC}=$ Sucrose, BSA = Bovine serum albumin, $\mathrm{EG}=$ Ethylene glycol, $\mathrm{ROS}=\mathrm{Reactive}$ oxygen species, FCS $=$ Fetal calf serum, PVP $=$ Polyvinylpyrrolidone, FBS $=$ Fetal bovine serum, PROH $=$ Propanediol, SSS $=$ Serum substitute supplement, HSA = Human serum album

Estradiol and progesterone concentrations detected in the culture medium of vitrified-thawed ovarian tissue were similar to those found in slow-freeze preserved tissues after 10 (Huang et al., 2008) and 14 (Li et al., 2007) days of in vitro culture. Estradiol concentrations from slow-frozen and vitrified ovaries were similar (Oktem et al., 2011) after three days of in vitro culture, and estradiol concentrations from vitrified ovaries were similar to those from fresh tissue after 21 days of in vitro culture (Isachenko et al., 2003).

Other characteristics have also been evaluated in in vitro cultured ovarian tissues after vitrification such as apoptosis, DNA fragmentation (Salehnia et al., 2012) and oocyte maturation (Zhang et al., 1995). Apoptosis was similar when compared to slow freezing tissue after ten days of in vitro culture (Huang et al., 2008). DNA fragmentation and oocyte maturation were similar to those reported from fresh tissue after one and 40 days of in vitro culture, respectively (Zhang et al., 1995).

Perspectives of the in vitro culture of isolated early stage ovarian follicles to produce mature oocytes for embryo production

As discussed earlier, a marked follicular loss occurs naturally in vivo. Thus, oocyte availability is a limiting fac- tor for this new reproductive technique development and expansion. The current methods for in vitro embryo production depends on a scarce supply of competent oocytes from large or preovulatory antral follicles, which are present in reduced numbers in the ovary (Telfer, 1998). Therefore, the use of preantral follicles, which represent $95 \%$ of the entire follicular reserve in the mammalian ovary, is an alternative to these limitations. In this regard, the development of an in vitro system that maximizes the oocyte potential of preantral follicles should be considered.

The isolation, cryopreservation and complete in vitro culture of preantral ovarian follicles may yield mature oocytes that can be utilized for further ART techniques, such as IVF and cloning, resulting in a greater number of in vitro produced embryos (Figueiredo et al., 2008).

In veterinary medicine, the main objective of follicular culture is to increase the productivity of high genetic value animals and to enable the preservation of species threatened with extinction. In addition, the technique represents an excellent alternative for the encouragement and support of research related to the pharmaceutical industry by means of toxicological assays of the effect of substances on the reproductive function of females (Cortvrindt \& Smitz, 2002).

In human medicine, follicular culture can be relevant 
to clinical reproduction, since it enables the development of alternative strategies for the reestablishment of fertility in women at risk of premature ovarian failure, especially those submitted to cancer treatment. In this respect, cryopreservation associated with ovarian follicle culture in vitro can represent an excellent strategy for the reversal or reduction of the impact on follicular loss. A large stock of preantral ovarian follicles can be cryopreserved and maintained at a low temperature for long periods of time before they become atretic or degenerated. These follicles could be later thawed and cultured in vitro to obtain mature oocytes, thus guaranteeing reproductive function in women.

Until today, few studies using in vitro culture of isolated preantral follicles have been performed in human models (Xu et al., 2009a; Vanacker et al., 2013). The success of this technique has been acquired in the mouse model with the achievement of healthy offspring (Xu et al., 2006). Promising results have also been shown in other animals such as sheep (Luz et al., 2012; Luz et al., 2013) and non-human primates (Zelinski et al., 2008; Xu et al., 2009b), but further studies are required in order to achieve increased mature oocytes for embryo production.

\section{CONCLUSIONS AND PERSPECTIVES}

Ovarian tissue vitrification has proved to be a valuable tool for female fertility preservation. The in vitro tissue culture method might be strategically used to restore reproductive capacity, especially in women submitted to cancer treatment. Although promising results regarding the combination of vitrification and in vitro culture of sheep or human ovarian follicles have been reported in the literature, further studies are needed to obtain viable embryos produced in vitro. Within this context, in view of the difficult execution of experiments with humans due to the limited material recovered from human reproduction clinics, there is a clear need to identify the most appropriate animal to be utilized as a model for human research.

Based on the reports described in the present review, sheep are believed to be a valid model for these studies proposal. It can be used as a model not only to improve the vitrification protocols, but also to achieve success in the production of embryos from immature oocytes grown in vitro.

\section{CONFLICT OF INTERESTS}

No conflict of interest have been declared.

\section{Corresponding author:}

Franciele Osmarini Lunardi

Laboratory of Manipulation of Oocytes and Ovarian Preantral Follicles (LAMOFOPA)

School of Veterinary Medicine of Ceará State University, Fortaleza, CE - Brazil

E-mail: lunardi.franciele@gmail.com

\section{REFERENCES}

Al-aghbari AM, Menino AR. Survival of oocytes recovered from vitrified sheep ovarian tissues. Anim Reprod Sci. 2002; 71:101-10.

Amorim CA, Curaba M, Van Langendonckt A, Dolmans MM, Donnez J. Vitrification as an alternative means of cryopreserving ovarian tissue. Reprod Biomed Online. 2011a; 23:160-86.

Amorim CA, David A, Van Langendonckt A, Dolmans MM, Donnez J. Vitrification of human ovarian tissue: effect of different solutions and procedures. Fertil Steril. 2011b; 95:1094-7.
Amorim CA, Dolmans MM, David A, Jaeger J, Vanacker J, Camboni A, Donnez J, Van Langendonckt A. (2012) Vitrification and xenografting of human ovarian tissue. Fertil Steril. 2012; 98:1291-8.e1-2.

Arav A, Revel A, Nathan Y, Bor A, Gacitua H, Yavin S, Gavish Z, Uri M, Elami A. Oocyte recovery, embryo development and ovarian function after cryopreservation and transplantation of whole sheep ovary. Hum Reprod. 2005; 20:3554-9.

Baerwald AR, Adams GP, Pierson R.A. Ovarian antral folliculogenesis during the human menstrual cycle: a review. Hum Reprod Update. 2012;18:73-91.

Bagchi A, Woods EJ, Critser JK. Cryopreservation and vitrification: recent advances in fertility preservation technologies. Expert Rev Med Devices. 2008;5:359-70.

Balasch J. (2010) Ageing and infertility: an overview. Gynecol Endocrinol. 2010;26:855-60.

Bartlewski PM, Baby TE, Giffin JL. Reproductive cycles in sheep. Anim Reprod Sci. 2011; 124:259-68.

Baudot A, Courbiere B, Odagescu V, Salle B, Mazoyer C, Massardier J, Lornage J. Towards whole sheep ovary cryopreservation. Cryobiology. 2007; 55: 236-48.

Bordes A, Lornage J, Demirci B, Franck M, Courbiere B, Guerin JF, Salle B. Normal gestations and live births after orthotopic autograft of vitrified-warmed hemi-ovaries into ewes. Hum Reprod. 2005;20:2745-8.

Cahill LP, Mauleon P. Influences of season, cycle and breed on follicular growth rates in sheep. J Reprod Fertil. 1980; 58:321-8.

Campbell BK, Telfer EE, Webb R, Baird DT. Ovarian autografts in sheep as a model for studying folliculogenesis. Mol Cell Endocrinol. 2000;163:131-9.

Chang HJ, Moon JH, Lee JR, Jee BC, Suh CS, Kim SH. Optimal condition of vitrification method for cryopreservation of human ovarian cortical tissues. J Obstet Gynaecol Res. 2011; 37:1092-101.

Cortvrindt RG, Smitz JEJ. Follicle culture in reproductive toxicology: a tool for in-vitro testing of ovarian function? Hum Reprod Update. 2002;8:243-54.

Courbiere B, Baudot A, Odagescu V, Salle B, Mazoyer C, Massardier J, Lornage J. Physical experimental studies to improve a vitrification procedure in whole sheep ovaries permeated with cryoprotectant agents. Hum Reprod. 2006; 21: i107.

Courbiere B, Massardier J, Salle B, Mazoyer C, Guerin $\mathrm{JF}$, Lornage J. Follicular viability and histological assessment after cryopreservation of whole sheep ovaries with vascular pedicle by vitrification. Fertil Steril. 2005; 84: 1065-71.

Courbiere B, Caquant L, Mazoyer C, Franck M, Lornage J, Salle B. Difficulties improving ovarian functional recovery by microvascular transplantation and whole ovary vitrification. Fertil Steril. 2009; 91:2697-706.

Courbiere B, Caquant L, Mazoyer C, Poirel MT, Franck M, Lornage J, Guerin JF, Salle B. Ovarian endocrine function recovery after vitrification and transplanta- 
tion of whole sheep ovary. Hum Reprod. 2007; 22: i227.

Donadeu FX, Ginther OJ. Changes in concentrations of follicular fluid factors during follicle selection in mares. Biol Reprod. 2002; 66:1111-8.

Donnez J, Dolmans MM. Fertility preservation in women. Nat Rev Endocrinol. 2013; 9:735-49

Donnez J, Dolmans MM, Demylle D, Jadoul P, Pirard C, Squifflet J, Martinez-Madrid B, Van Langendonckt A. Livebirth after orthotopic transplantation of cryopreserved ovarian tissue. Lancet. 2004; 364: 1405-10.

Donnez J, Silber S, Andersen CY, Demeestere I, Piver P, Meirow D, Pellicer A, Dolmans MM. Children born after autotransplantation of cryopreserved ovarian tissue. A review of 13 live births. Ann Med. 2011;43:437-50.

Fathi R, Valojerdi MR, Eimani $H$, Hasani F, Yazdi PE, Ajdari Z, Tahaei LS. Sheep ovarian tissue vitrification by two different dehydration protocols and needle immersing methods. Cryo Letters. 2011; 32:51-6.

Figueiredo JR, Rodrigues APR, Amorim CA, Silva JRV. Manipulação de Oócitos Inclusos em Folículos Ovarianos Pré-antrais. In: Gonçalves PBD, Figueiredo JR, Freitas VJF, eds. Biotécnicas Aplicadas à Reprodução Animal. São Paulo: Editora Roca, 2008. p.303-327.

Gandolfi F, Paffoni A, Brambilla EP, Bonetti S, Brevini TAL, Ragni G. Efficiency of equilibrium cooling and vitrification procedures for the cryopreservation of ovarian tissue: comparative analysis between human and animal models. Fertil Steril. 2006;85:1150-6.

Gartner LP, Hiatt JL, (eds) Tratado de histologia: Introdução à Histologia e Técnicas Básicas-de Histologia. Rio de Janeiro: Guanabara Koogan, 2003.

Gerritse R, Beerendonk CCM, Tijink MSL, Heetkamp A, Kremer JAM, Braat DDM, Westphal JR. Optimal perfusion of an intact ovary as a prerequisite for successful ovarian cryopreservation. Hum Reprod. 2008; 23:329-35

Goding JR, McCracke JA, Baird DT. Study of ovarian function in ewe by means of a vascular autotransplantation technique. J Endocrinol. 1967;39:37-52.

Gosden RG, Baird DT, Wade JC, Webb R. Restoration of fertility to oophorectomized sheep by ovarian autografts stored at -196 degrees C. Hum Reprod. 1994;9:597-603.

Gougeon A. Dynamics of follicular-growth in the human - a model from preliminary-results. Hum Reprod. 1986;1:81-7

Gougeon A, Chainy GBN. Morphometric studies of small follicles in ovaries of women at different ages. J Reprod Fertil. 1987; 81:433-42.

Hasegawa A, Mochida N, Ogasawara T, Koyama K. Pup birth from mouse oocytes in preantral follicles derived from vitrified and warmed ovaries followed by in vitro growth, in vitro maturation, and in vitro fertilization. Fertil Steril. 2006; 86:1182-92

Huang LL, Mo YQ, Wang WJ, Li Y, Zhang QX, Yang DZ. Cryopreservation of human ovarian tissue by solid-surface vitrification. Eur ] Obstet Gynecol Reprod Biol. 2008; 139:193-8.
Irving-Rodgers HF, Catanzariti KD, Aspden WJ, D'Occhio MJ, Rodgers RJ. Remodeling of extracellular matrix at ovulation of the bovine ovarian follicle. Mol Reprod Dev. 2006; 73:1292-302.

Isachenko E, Isachenko V, Nawroth F, Rahimi G, Kreienberg R, Reinsberg J, Weiss J. Human ovarian tissue preservation: is vitrification acceptable method for assisted reproduction? Cryo Letters. 2008; 29: 301-14.

Isachenko E, Isachenko V, Rahimi G, Nawroth F. Cryopreservation of human ovarian tissue by direct plunging into liquid nitrogen. EurJ Obstet Gynecol Reprod Biol. 2003;108: 186-93

Isachenko $\mathrm{V}$, Montag $\mathrm{M}$, Isachenko $\mathrm{E}$, van der Ven $\mathrm{K}$, Dorn C, Roesing B, Braun F, Sadek F, van der Ven H. Effective method for in-vitro culture of cryopreserved human ovarian tissue. Reprod Biomed Online. 2006;13:228-34.

Kagawa N, Silber S, Kuwayama M. Successful vitrification of bovine and human ovarian tissue. Reprod Biomed Online. 2009;18:568-77 Kawamura K, Cheng $Y$, Suzuki N, Deguchi M, Sato $Y$, Takae S, Ho CH, Kawamura N, Tamura M, Hashimoto S, Sugishita $Y$, Morimoto $Y$, Hosoi $Y$, Yoshioka N, Ishizuka B, Hsueh AJ. Hippo signaling disruption and Akt stimulation of ovarian follicles for infertility treatment. Proc Natl Acad Sci U S A. 2013;110:17474-9.

Keros V, Xella S, Hultenby K, Pettersson K, Sheikhi M, Volpe A, Hreinsson J, Hovatta O. Vitrification versus controlled-rate freezing in cryopreservation of human ovarian tissue. Hum Reprod. 2009;24:1670-83

Kheirabadi BS, Fahy GM. Permanent life support by kidneys perfused with a vitrifiable (7.5 molar) cryoprotectant solution. Transplantation. 2000;70:51-7.

Lavranos TC, Rodgers HF, Bertoncello I, Rodgers RJ. Anchorage-independent culture of bovine granulosa-cells - the effects of basic fibroblast growth-factor and dibutyryl-camp on cell-division and differentiation. Exp Cell Res. 1994; 211:245-51.

Lee $\mathrm{SH}$, Shin CS, Ko JJ, Lee HC, Park C, Lee KA. In vitro culture of the human adult ovarian tissues after vitrification: comparison among detection methods of the culture effect. Fertil Steril, 2000; 74:S161.

Li YB, Zhou CQ, Yang GF, Wang Q, Dong Y. Modified vitrification method for cryopreservation of human ovarian tissues. Chin Med J (Engl). 2007;120:110-4.

Lornage J, Courbière $B$, Mazoyer C, Odagescu V, Baudot A, Bordes A, Poirel MT, Franck M, Salle B. [Ovarian tissue vitrification: cortex and whole ovary in sheep]. Gynecol Obstet Fertil. 2006; 34:746-53

Lucci CM, Silva RV, Carvalho CA, Figueiredo R, Báo N. Light microscopical and ultrastructural characterization of goat preantral follicles. Small Rumin Res. 2001; 41:61-9.

Lun S, Smith P, Lundy T, O'Connell A, Hudson N, McNatty KP. Steroid contents of and steroidogenesis in vitro by the developing gonad and mesonephros around sexual differentiation in fetal sheep. J Reprod Fertil. 1998;114:131-9.

Lunardi FO, Araujo VR, Faustino LR, Carvalho AA, Goncalves RFB, Bass CS, Bao SN, Name KPO, Campello CC, de Figueiredo JR, Rodrigues APR. Morphologic, viability and 
ultrastructural analysis of vitrified sheep preantral follicles enclosed in ovarian tissue. Small Rumin Res. 2012; 107: 121-30.

Lundy T, Smith P, O'Connell A, Hudson NL, McNatty KP. Populations of granulosa cells in small follicles of the sheep ovary. J Reprod Fertil. 1999;115:251-62.

Luz VB, Araujo VR, Duarte ABG, Silva GM, Chaves RN, Brito IR, Serafim MKB, Campello, C. Feltrin CC, Bertolini M, Almeida AP, Santos RR, Figueiredo JR. Kit ligand and insulin-like growth factor I affect the in vitro development of ovine preantral follicles. Small Rumin Res.2013;115: 99-102.

Luz VB, Araújo VR, Duarte AB, Celestino JJ, Silva TF, Magalhães-Padilha DM, Chaves RN, Brito IR, Almeida AP, Campello CC, Feltrin C, Bertolini M, Santos RR, Figueiredo JR. Eight-Cell Parthenotes Originated From In Vitro Grown Sheep Preantral Follicles. Reprod Sci. 2012;19:1219-25.

McGee EA, Hsueh AJ. Initial and cyclic recruitment of ovarian follicles. Endocr Rev. 2000; 21:200-14. Melo MA, Oskam IC, Celestino JJ, Carvalho AA, Castro SV, Figueiredo JR, Rodrigues AP, Santos RR. Adding ascorbic acid to vitrification and IVC medium influences preantral follicle morphology, but not viability. Reprod Domest Anim. 2011;46:742-5.

Mohammadpour AA. Comparative Histomorphological Study of Ovary and Ovarian Follicles in Iranian Lori-Bakhtiari Sheep and Native Goat. Pak J Biol Sci. 2007;10:673-5.

Munn CS, Kiser LC, Wetzner SM, Baer JE. Ovary volume in young and premenopausal adults - us determination - work in progress. Radiology. 1986;159:731-2.

Oktem O, Alper E, Balaban B, Palaoglu E, Peker K, Karakaya C, Urman B. Vitrified human ovaries have fewer primordial follicles and produce less antimullerian hormone than slow-frozen ovaries. Fertil Steril. 2011;95:2661-4.e1

Rahimi G, Isachenko E, Sauer H, Isachenko V, Wartenberg M, Hescheler J, Mallmann P, Nawroth F. Effect of different vitrification protocols for human ovarian tissue on reactive oxygen species and apoptosis. Reprod Fertil Dev. 2003;15:343-9.

Rahimi G, Isachenko $E$, Isachenko $V$, Sauer $H$, Wartenberg M, Tawadros S, Hescheler J, Mallmann P, Nawroth F. Comparison of necrosis in human ovarian tissue after conventional slow freezing or vitrification and transplantation in ovariectomized SCID mice. Reprod Biomed Online. 2004;9:187-93.

Rahimi G, Isachenko $\mathrm{V}$, Todorov $\mathrm{P}$, Tawadros $\mathrm{S}$, Mallmann $P$, Nawaroth F, Isachenko E. Apoptosis in human ovarian tissue after conventional freezing or vitrification and xenotransplantation. Cryo Letters. 2009;30:300-9.

Rahimi G, Isachenko $V$, Kreienberg $R$, Sauer $H$, Todorov P, Tawadros S, Mallmann P, Nawroth F, Isachenko E. Re-vascularisation in human ovarian tissue after conventional freezing or vitrification and xenotransplantation. Eur J Obstet Gynecol Reprod Biol. 2010; 149:63-7 Rall WF, Fahy GM. Ice-free cryopreservation of mouse embryoat -196 degrees $C$ by vitrification. Nature. $1985 ; 313: 573-5$.

Salehnia M, Sheikhi M, Pourbeiranvand S, Lundqvist M. Apoptosis of human ovarian tissue is not increased by either vitrification or rapid cooling. Reprod Biomed Online. 2012; 25:492-9.

Schneyer AL, Fujiwara T, Fox J, Welt CK, Adams J, Messerlian GM, Taylor AE. Dynamic changes in the intrafollicular inhibin/activin/follistatin axis during human follicular development: Relationship to circulating hormone concentrations. J Clin Endocrinol Metab. 2000; 85:3319-30.

Shaw JM, Oranratnachai A, Trounson AO. Fundamental cryobiology of mammalian oocytes and ovarian tissue. Theriogenology. 2000; 53:59-72.

Smith P, O WS, Hudson NL, Shaw L, Heath DA, Condell L, Phillips DJ, McNatty KP. Effects of the booroola gene (FecB) on body-weight, ovarian development and hormone concentrations during fetal life. J Reprod Fertil. 1993; 98:4154.

Soede NM, Langendijk P, Kemp B. Reproductive cycles in pigs. Anim Reprod Sci. 2011; 124:251-8. Telfer EE. In vitro models for oocyte development. Theriogenology. 1998; 49: 451-60. Torre A, Momier M, Mazoyer C, Selva J, Salle B, Lornage J. Validation of a new metabolic marker to assess the vascular viability of vitrified whole sheep ovaries. Hum Reprod. $2012 ; 27: 1811-21$

van den Hurk R, Zhao J. Formation of mammalian oocytes and their growth, differentiation and maturation within ovarian follicles. Theriogenology. 2005; 63:1717-51.

Vanacker J, Luyckx V, Amorim C, Dolmans MM, Van Langendonckt A, Donnez J, Camboni A. Should we isolate human preantral follicles before or after cryopreservation of ovarian tissue? Fertil Steril. 2013; 99:1363-8.e2

VandeBerg JL. Need for primate models in biomedical research. Gynecol Obstet Invest. 2004; 57:6-8

Wallace WH, Anderson RA, Irvine DS. Fertility preservation for young patients with cancer: who is at risk and what can be offered? Lancet Oncol. 2005; 6:209-18.

Wallace WH, Kelsey TW. Human Ovarian Reserve from Conception to the Menopause. PLoS One. 2010; 5:e8772

Wang X, Catt S, Pangestu M, Temple-Smith P. Successful in vitro culture of pre-antral follicles derived from vitrified murine ovarian tissue: oocyte maturation, fertilization, and live births. Reproduction. 2011;141: 183-91

Wang $Y$, Xiao $Z$, Li L, Fan W, Li SW. Novel needle immersed vitrification: a practical and convenient method with potential advantages in mouse and human ovarian tissue cryopreservation. Hum Reprod. 2008; 23: 2256-65

WolfDP.Thenon-human primateoocyteandembryoasamodel for women, or is it vice versa? Theriogenology. 2008; 69:31-6

Woodruff TK. Preserving fertility during cancer treatment. Nat Med. 2009;15:1124-5.

Xiao Z, Wang Y, Li L, Luo S, Li SW. Needle immersed vitrification can lower the concentration of cryoprotectant in human ovarian tissue cryopreservation. Fertil Steril. 2010; 94:2323-8.

Xu M, Kreeger PK, Shea LD, Woodruff TK. Tissue-engi- 
neered follicles produce live, fertile offspring. Tissue Eng. $2006 ; 12: 2739-46$.

Xu M, Barrett SL, West-Farrell E, Kondapalli LA, Kiesewetter SE, Shea LD, Woodruff TK. In vitro grown human ovarian follicles from cancer patients support oocyte growth. Hum Reprod. 2009a; 24:2531-40

Xu M, West-Farrell ER, Stouffer RL, Shea LD, Woodruff TK, Zelinski MB. Encapsulated Three-Dimensional Culture Supports Development of Nonhuman Primate Secondary Follicles. Biol Reprod. 2009b;81:587-94

Yang MY, Fortune JE Testosterone stimulates the primary to secondary follicle transition in bovine follicles in vitro. Biol Reprod. 2006;75:924-32
Zelinski M, Xu M, West E, Lawson M, Shea L, Woodruff $T$, Stouffer $R$ An alginate matrix supports the three-dimensional architecture of the nonhuman primate follicle and permits coordinated development of preantral follicles to small antral follicles in vitro. Biol Reprod. 2008; 78:204.

Zhang J, Liu J, Xu KP, Liu B, DiMattina M. Extracorporeal development and ultrarapid freezing of human fetal ova. J Assist Reprod Genet. 1995;12: 361-8.

Zhou XH, Wu YJ, Shi J, Xia YX, Zheng SS Cryopreservation of human ovarian tissue: Comparison of novel direct cover vitrification and conventional vitrification. Cryobiology. 2010; 60:101-5 